\section{Clark's demise halts NASA experiment in remote sensing}

[WASHINGTON] The second of two Earthobserving satellite projects designed to help jump-start a commercial remote sensing industry has been scrapped by the US space agency NASA after cost and schedule overruns. The cancellation of the Clark project follows the failure of its companion satellite, Lewis, shortly after its launch in August (see Nature 389, 108; 1997).

The two spacecraft were intended to develop techniques and technologies that would be useful to future Earth-observing satellites, including hyperspectral imaging and the ability to selectively 'edit' out undesirable images obscured by cloud cover to conserve data.

NASA has long known that Clark was in trouble. The project was announced in June 1994 and was due to launch in March 1996, but difficulties with some of the spacecraft's subsystems and delays associated with a new rocket built by Lockheed Martin Aerospace pushed the date back by more than two years.

While Clark was being developed, the company originally contracted to build it, CTA Inc. of Rockville, Maryland, was purchased by Orbital Sciences Corp. of Dulles, Virginia, which also makes the Pegasus rocket. NASA had hoped that Orbital would solve Clark's management woes, but the cost overruns and technical problems continued.

After a review team at NASA's Goddard Space Flight Center recommended cancellation earlier this year, agency administrator Daniel Goldin acted on repeated threats to terminate any agency development project that runs more than 15 per cent over budget.

The space agency spent about $\$ 55$ million on Clark, but not all of that is lost. NASA will retain launch-vehicle services from Lockheed Martin, and some of the satellite subsystems can be used on future projects. Developers of the software algorithms for cloud editing expect to use the technique in other missions.

A report on the failure of the $\$ 71$ million Lewis satellite is due from NASA this month. A panel chaired by Christine Anderson, director for space vehicles at the Air Force Research Laboratory in Albuquerque, New Mexico, investigated the incident and has already presented its findings to NASA.

TRW Inc., which built and operated Lewis, has completed an internal investigation, but is not commenting publicly on the reasons for the failure. NASA sources have said that deficiencies in tracking and monitoring the satellite's progress after launch were partly to blame. Lewis might have been saved, they say, if spacecraft operators been present in the control room during the period of several hours when the spacecraft first began to spin out of control. Tony Reichhardt

\title{
Survey results boost calls for new teaching efforts
}

[WASHINGTON] An international study showing that 17-year-olds in the United States are performing poorly in mathematics and science could serve as a wake-up call for action to raise school standards, according to US scientific leaders.

"This is a great opportunity to mobilize scientists and engineers," says Bruce Alberts, president of the National Academy of Sciences, referring to the latest results from the Third International Mathematics and Science Study (TIMSS). But Alberts and other scientific leaders stress that any such response will need to be undertaken voluntarily at a grass-roots level, and be directed at each of the 16,000 autonomous district authorities that control US schools.

Unlike the governments of Sweden, Norway, Denmark and most of the other states that comfortably out-performed the United States in the study, the US federal government lacks the power to take direct action to reform science education in schools. "Education has been taken away from federal control," Alberts says. "We're not going to fight that battle again".

The study, which compared the performance in mathematics and science of 17-year-olds in 21 countries, as well as the performance of advanced students in these subjects in 16 of the countries, placed US students in the lowest band in every category.

The United States ranked third-last in mathematics - above Cyprus and South Africa - and sixth-last in science. The performance of its advanced students was even weaker: they came second-last in mathematics and last in science. The study did not include most Asian nations or the United Kingdom, so the comparison was chiefly with European nations, Canada and South Africa.

President Bill Clinton responded to the results by calling for more professional development for teachers and more widespread acceptance of national standards in schools. "I hope that eventually we will have every state testing their children in basics and measuring them by a common national standard," he said.

Neal Lane, director of the National Science Foundation, took comfort from the fact that the US has fared better in a 1995 TIMSS survey of nine-year-olds. Lane said that younger children were benefiting from recent government initiatives and predicted that "we can expect to see improvement in their performance at higher grade levels" in future. TIMSS will report a new comparison of 13-year-olds next year.

But few observers share Lane's belief that the United States will have improved by then.

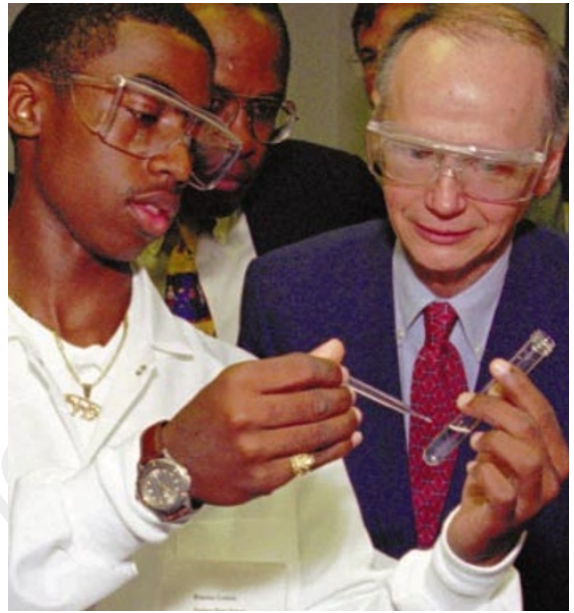

Local knowledge: Richard W. Riley, Secretary of Education, visits a Baltimore high school.

Some science educators see the TIMSS study as the inevitable result of a fragmented education system, in which attempts by the federal government to impose standards on schools has opened up deep political divisions.

Clinton has proposed various initiatives to expand the role of the Department of Education in schools, but the Republican Congress values the right of states and local school boards to set their own education policies. Republicans have strongly opposed national testing of students, and were until recently seeking to abolish the department.

"We are very concerned about the TIMSS results," says Bill McCarthy, a spokesman for the Education and Workforce Committee in the House of Representatives. "But we still believe that education is best handled as a local issue."

This desire for autonomy is at its strongest where it affects the teaching of history and other politically charged topics. But the teaching of Darwinian evolution has also generated frequent controversy. Vernon Ehlers (Republican, Michigan), the vicechairman of the Science Committee in the House of Representatives, says that evolution is "probably the only example" of such contention in science, and argues that Republicans will support the use of national science teaching standards by school districts.

Such standards have been developed and published by the National Academy of Sciences. Alberts says that, although the effort was publicly funded, "it has been accepted as a national, not a federal, standard". But the decision to use the standards rests with each of the thousands of school boards. So when the federal government is unable to intervene, what is going to influence their autonomous actions? "Maybe these test results will," says Alberts. ColinMacilwain 